Volume and Issues Obtainable at Center for Sustainability Research and Consultancy

Journal of Accounting and Finance in Emerging Economies

ISSN: 2519-0318 \& ISSN (E): 2518-8488

Volume 7: Issue 4 December 2021

Journal homepage: www.publishing.globalcsrc.org/jafee

\title{
Financial Inclusion between Financial Innovation and Economic Growth: A Study of Lower Middle Income Economies
}

*Hina Affandi, Faculty of Management Sciences, Foundation University Islamabad, Pakistan

Qaisar Ali Malik, Faculty of Management Sciences, Foundation University Islamabad, Pakistan

*Corresponding author's email: hinaaffandi@gmail.com

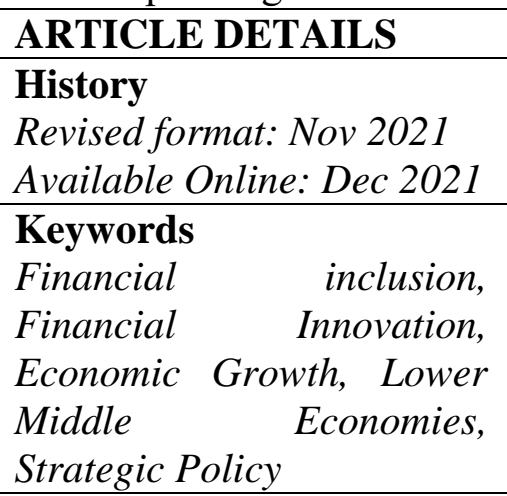

JEL Classification

P34, P43

\section{ABSTRACT}

Purpose: Financial inclusion is a key concern that has achieved much impulsion in the last two decades internationally. It has the scope of reporting of financial scheme and institutions to the underserved community in the economy. This study examined the effect of financial innovation on economic growth with the mediation of financial inclusion.

Design/Methodology/Approach: To address the relationship researchers in this study have used measures from a dataset of low and lower middle income group economies over a sample period from 2010-2017.

Findings: The results of this study shows that financial innovation creates opportunities for financially excluded segment of the society which results in financial inclusion that leads to economic growth of low and lower middle economies.

Implications/Originality/Value: Study will provide new evidence that contributes new ways to improve low and lower middle economies towards economic growth by promoting financial innovation and financial inclusion

\section{OPEN ACCESS}

(C) 2021, The authors, under a Creative Commons AttributionNonCommercial 4.0

Recommended citation: Affandi, H. and Malik, Q. A. (2021). Financial Inclusion between Financial Innovation and Economic Growth: A Study of Lower Middle Income Economies. Journal of Accounting and Finance in Emerging Economies, 7 (4), 913-920

\section{Introduction}

Financial inclusion has turn out to be an imperative approach following the recent worldwide financial predicament. Financial inclusion has acknowledged a lot of deliberation since the late 1990s, as the guiding principle making matter of generally expelled community and many researches concerning the financial exclusion of generally excluded public has materialized (Leyshon \& Thrift 1993; 1994; 1995; Collard 2010). The growth of financial inclusion according to the household savings, capital growth, technological modernization, increase in income, and financial willpower is playing vital role in economic growth. Financial inclusion is the way to variety of valued financial product and financial services have developed into focus of substantial attention intended for governments, researchers, and public. Financial inclusion helps economies to cope up with the recent economic challenges and achieve economic stability and growth. 
Financial inclusion applies a gigantic effect on economic development through remunerations resulting from the access of financial product and services to the individuals in the economy. According to Alliance for Financial Inclusion, (2015) improvement in financial inclusion and business development offer massive benefits to in general whole economy in context of employment prospect and tax expenses that add to the nationalized revenues. There is a need for understanding the association among financial inclusion with economic growth. It has turn out to be a noteworthy apprehension in national development. Financial innovation is the course of action of generating innovative financial technologies offered by financial institutions. Financial innovation includes institutional aspect, product base aspect, and the process aspect. Financial innovation develops the provision of financial products and financial services and also improves access to financial services and financial product (Lee et.al. 2019). Many researchers verified that financial innovation is positively connected with the national economic growth (Laeven, Levine, \& Michalopoulos, 2015; Beck, Chen, Lin, \& Song, 2016).

Financial innovations include mobile wallets that are making cashless payments more suitable, quick and valuable to customer and to encourage a further frequent utilization of non-cash mechanism (Semerikova, 2019). A financial innovation raises the reimbursement to the individuals by civilizing the excellence of the understanding of using cashless payments mechanism. When people recognized financial innovations as simple and easier to apply as a result they may possibly implement them quickly and employ them regularly (Loh et al., 2019; Liu et al., 2020). Miller in 1986 had found financial innovation is considered as a vital ingredient of the economic scenery (Tufano, 2003). Financial innovation is act of creation, continuing research and development, dissemination or implementation of innovative financial product, financial services or financial thoughts (Tufano, 2003). Kim et al. (2018) found that there is a noteworthy association between financial inclusion and economic growth in Organization of Islamic Cooperation (OIC) economies. In the financial markets, financial innovation is considered as a way to reduce interior and exterior financial restriction (Silber, 1983) to accomplish superior economic competence (Merton, 1995, Laeven et al., 2015).

Monetary policy rate have long term effect on real rates primarily through alteration in investors' risk-taking activities and their impact on premiums (Hanson and Stein, 2015). Nakamura and Steinsson (2018) found in their study that monetary policy revelation direct to re-evaluations regarding the economy and consequently have a tendency to shift the predictable rates constituent of medium and long term yields. Monetary policy choices are arrived on the foundation of agreement (Hammond, 2012) after allowing for key economic growth that creates risk of inflation.

The insurance market saturation is measured to be a necessary ingredient of financial inclusion which directs the economy to economic growth (Pradhan et al., 2016). Boukhatem (2016) considered that the persistence of the effect of financial inclusion on economic growth that includes reduction in poverty. Financial inclusion accepted as a method that scripts progression in capacity, value, effectiveness and competence of conciliator financial services, which assist in improving lives, promote opportunity and fortify economies. Savings at local level are encouraged all the way through financial inclusion which leads to improved, productive and fruitful investments in local industry (Mlambo and Ncube, 2011; Babajide et al., 2015; Arun and Kamath, 2015).

Research studies found the connection of financial inclusion with economic growth, financial inclusion with economic steadiness, and discrimination (Sahay et al., 2015). As a result of financial inclusion there is increased in access of financial products and services by businesses and households that lead to enhanced economic growth. Low level of financial inclusion leads to negative or low economic growth in some developed economies. Increasing access to financial 
products and services other than credit was institute to be valuable to development to financial stability. This study contributes to existing literature through variables under study financial innovation, monetary policy rate impact on financial inclusion that contributes towards economic growth in low and lower middle income economies. This study will also provide new evidence that contributes new ways to improve low and lower middle economies towards economic growth by promoting financial innovation and financial inclusion.

\section{Empirical Framework}

The model of the study is as follows:

$F G i t=\beta 0+\beta 1 F I N N i t+\beta 2 M P R i t+\varepsilon i t$ .equation (1)

For Mediation:

$$
\text { FGit }=\beta 0+\beta 1 F \text { Iit }+\beta 2 M P R i t+
$$

Eit..... equation (2)

FGit $=\beta 0+\beta 1 F I N N i t+\beta 2 M P R i t+$

Eit. equation (3)

$F G i t=\beta 0+\beta 1 F I N N i t+\beta 2 F I+\beta 3 M P R i t+$

cit. .equation (4)

\section{Research Design}

Secondary data has been utilized for the analysis of variable. Secondary data of financial innovation, monetary policy rate, financial inclusion and economic growth has been collected through Global Findex Database, international financial statistics and World Bank development indicators. Quantitative research method has been used in this study. The units of analysis for the study were low and lower middle income economies. A total sample size of study is 500 . This study use data of 50 countries over the year 2010-2019. Furthermore, convenient sampling technique has been used in selecting the sample. Deductive approach has been used for quantitative data analysis.

The measures used for financial inclusion includes penetration, availability and usage. Penetration includes number of financial institutes per 10,000 people calculated as total number of financial institutes divided by residents of country, number of bank staff per 10,000 people calculated as total number of bank staff divided by residents of country, number of financial institutes per 10,000 square kilometer calculated as total number of financial institutes divided by region and number of bank staff per 10,000 square kilometer calculated as total number of bank staff divided by area. Availability includes savings deposit per capita calculated as savings deposit divided by residents of country, loans per capita calculated as loan divided by residents of country and insurance density calculated as quality income divided by residents of country. Usage includes deposit ratio calculated as deposit divided by GDP, loan ratio calculated as loan divided by GDP and insurance depth calculated as quality revenue divided by GDP. Financial innovation measures as ratio of Narrow-to-Broad money. Real GDP per capital is used as a proxy 


\section{Empirical Results and Discussion}

The mean, minimum, maximum, minimum and standard deviation value for financial innovation, monetary policy, financial inclusion and economic growth is described in table 1.

Table 1: Descriptive Statistics

\begin{tabular}{|c|c|c|c|c|c|c|c|c|c|c|c|c|c|}
\hline & $\begin{array}{c}\text { Finan } \\
\text { cial } \\
\text { Innov } \\
\text { ation }\end{array}$ & $\begin{array}{c}\text { Moneta } \\
\text { ry } \\
\text { Policy } \\
\text { Rate }\end{array}$ & $\begin{array}{c}\text { Total } \\
\text { Numbe } \\
\text { r of } \\
\text { Financi } \\
\text { al } \\
\text { Institut } \\
\text { es / } \\
\text { Reside } \\
\text { nts of } \\
\text { Countr } \\
y\end{array}$ & $\begin{array}{c}\text { Total } \\
\text { Number Of } \\
\text { Bank Staff } \\
\text { / Residents } \\
\text { Of Country }\end{array}$ & $\begin{array}{c}\text { Total } \\
\text { Numbe } \\
\text { r Of } \\
\text { Financi } \\
\text { al } \\
\text { Institut } \\
\text { es } \\
\text { /Region }\end{array}$ & $\begin{array}{c}\text { Total } \\
\text { Numbe } \\
\text { r Of } \\
\text { Bank } \\
\text { Staff / } \\
\text { Area }\end{array}$ & $\begin{array}{c}\text { Savings } \\
\text { Deposit } \\
\text { / } \\
\text { Residen } \\
\text { ts Of } \\
\text { Countr } \\
y\end{array}$ & $\begin{array}{c}\text { Loan / } \\
\text { Residen } \\
\text { ts Of } \\
\text { Country }\end{array}$ & $\begin{array}{c}\text { Qualit } \\
\text { y } \\
\text { Income } \\
\text { /Reside } \\
\text { nts Of } \\
\text { Countr } \\
\text { y }\end{array}$ & $\begin{array}{c}\text { Depos } \\
\text { it / } \\
\text { GDP }\end{array}$ & $\begin{array}{c}\text { Loa } \\
\text { n / } \\
\text { GD } \\
\text { P }\end{array}$ & $\begin{array}{l}\text { Quality } \\
\text { Revenu } \\
\text { e / GDP }\end{array}$ & $\begin{array}{c}\text { Economic } \\
\text { Growth }\end{array}$ \\
\hline Mean & 3.64 & 12.05 & 0.09 & 0.08 & 2.33 & 0.03 & 0.02 & 0.08 & 0.07 & 0.06 & 0.97 & 1.09 & 0.84 \\
\hline Maximum & 4.28 & 15.00 & 0.11 & 1.25 & 3.21 & 0.98 & 0.97 & 0.56 & 0.91 & 0.11 & 0.83 & 1.13 & 2.60 \\
\hline Minimum & 2.55 & 9.00 & 0.03 & 1.11 & 1.02 & 0.61 & 0.20 & 0.03 & 0.04 & 0.03 & 0.23 & 0.26 & -1.96 \\
\hline Std. Dev. & 0.33 & 0.84 & 0.28 & 0.36 & 0.96 & 0.35 & 0.07 & 0.02 & 0.03 & 0.91 & 0.81 & 1.25 & 0.78 \\
\hline
\end{tabular}

Table 2 describes the correlation among variables. There is positive significant relationship among financial innovation and economic growth. Results also show positive significant relationship among financial innovation and financial inclusion. Financial inclusion and economic growth shows positive significant connection. Results of this study show that introducing new innovative financial products and services leads to financial inclusion which directs the economy to economic growth. Financial innovation initiates innovative financial organizations, innovative financial products and better financial services that are preeminent in explaining the effect of financial innovation on economic growth through mediation of financial inclusion (Chou \& Chin, 2011; Wachtel, 2003). 


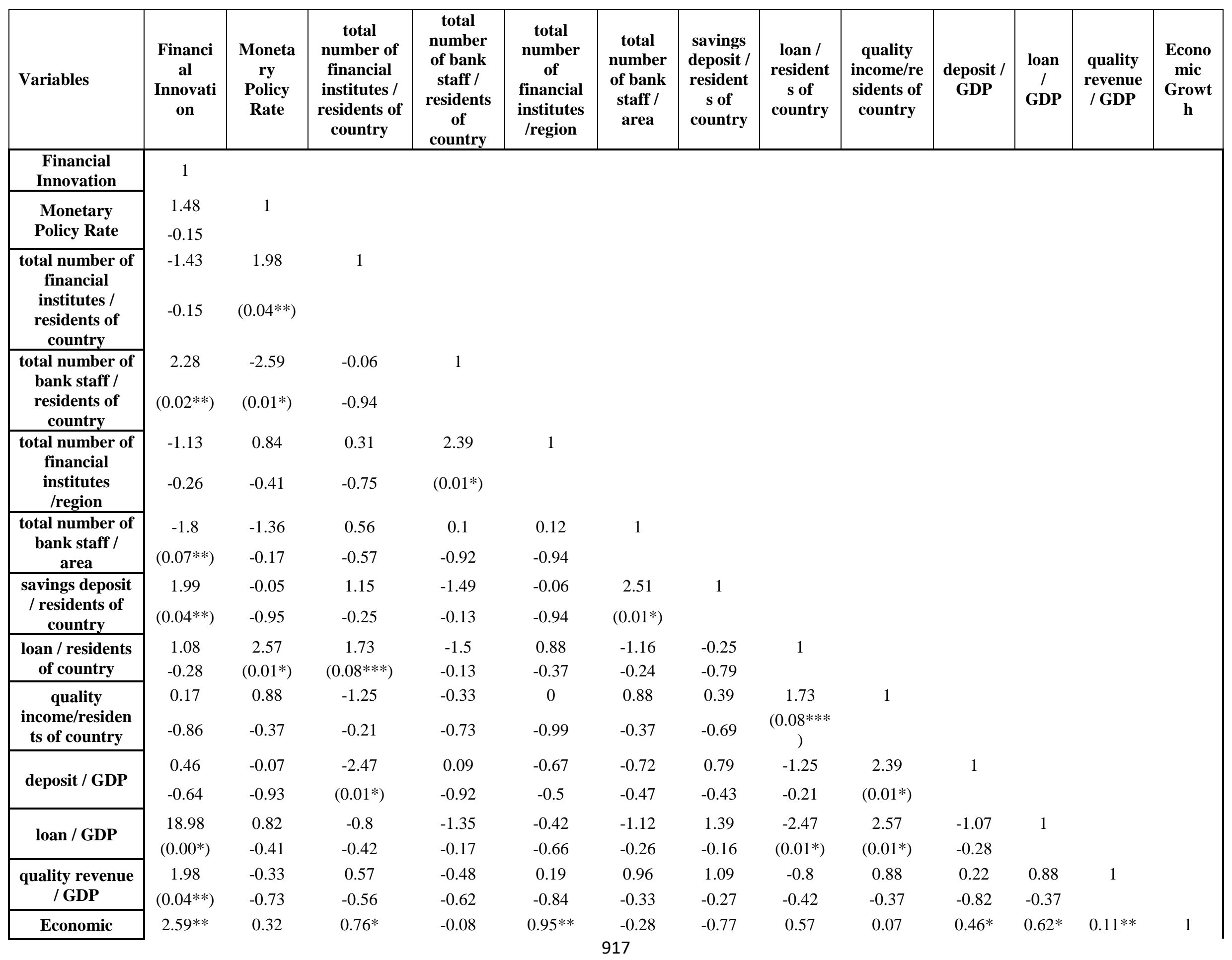


Growth $\quad(0.01 *)$
$-0.74$

$-0.44$

$-0.93$

$-0.34$

$-0.77$

$-0.43$

$-0.56$

$-0.93$

$-0.63$

$-0.53$

$-0.9$ significance of variables at $0.01,0.05$ and 0.10 levels.

Table 3. Dependent Variable is Economic Growth - Analysis without Mediation

\begin{tabular}{|c|c|c|}
\hline Variable & Coefficient & Prob. \\
\hline Financial Innovation & $-2.34 \mathrm{E}-11$ & 0.4411 \\
\hline Monetary Policy Rate & 0.789731 & 0.03 \\
\hline R-squared & 0.110 & \\
\hline Adjusted R-squared & 0.109 & \\
\hline F-statistic & 10.549 & \\
\hline $\operatorname{Prob}($ F-statistic) & 0.000 & \\
\hline
\end{tabular}

Table 4. Dependent Variable is Economic Growth - Detailed Mediation Analysis

\begin{tabular}{lrr}
\hline \multicolumn{1}{c}{ Variable } & Coefficient & Prob. \\
\hline Financial Innovation & $2.64 \mathrm{E}-10$ & 0.03 \\
Monetary Policy Rate & $-1.24 \mathrm{E}-18$ & 0.08 \\
total number of financial institutes / residents of country & 0.030 & 0.36 \\
total number of bank staff / residents of country & 96.234 & 0.4 \\
total number of financial institutes /region & -56.903 & 0.00 \\
total number of bank staff / area & -0.359 & 0.84 \\
savings deposit / residents of country & 11.140 \\
loan / residents of country & 0.01 \\
quality income/ residents of country & 459.829 \\
deposit / GDP & 37.770 \\
loan / GDP & 0.00 \\
quality revenue / GDP & 0.04 \\
R-squared & & 0.01 \\
Adjusted R-squared & & $-2.14 \mathrm{E}-20$ \\
F-statistic & 0.11 \\
Prob(F-statistic) & 0.4590 & 0.0215 \\
\hline
\end{tabular}


Probability value is seen for accepting or rejecting the hypothesis. $\mathrm{P}$ value should be equal or less than 0.01 at $1 \%$ confidence interval level, equal or less than 0.05 at $5 \%$ confidence interval level and equal or less than 0.10 at $10 \%$ confidence interval level. Financial Innovation has significant impact on economic growth. Monetary policy rate is taken as a control variable and has significant impact on economic growth at 10\% confidence interval level. Table 3 and table 4 shows the regression analysis for the model. There is significant relation among independent variable financial innovation, mediating variable financial inclusion and dependent variable economic growth.

\section{Conclusion}

Financial innovation leads to effective and efficient an economic system that is principally imperative for supporting economic development for the reason that the effectiveness of investment will take the limelight the amount of investment is the driver of the economic growth (Qamruzzaman \& Jianguo, 2018). Financial innovation develops the financial sector of the economy that brings together all stakeholders in the financial system to create better economic system. It improves the economic growth and economic wealth for the economic stakeholders. Financial innovation adds up financially excluded segment of the economy. As financial innovation creates the innovative variety of financial products and services that is attractive for many economics stakeholders which results in financial inclusion that leads to economic growth. This study results certified that financial innovation leads to financial inclusion which results in economic growth. The findings of this study drawn attention to new research areas. First this model can also be tested on other categories of economies. Mixed research method that is primary and secondary data can be incorporated in future research studies for better results. Qualitative research can also be carried out for triangulation purpose. New micro and macro level variables can also be introduced in existing model.

\section{References}

Alliance for Financial Inclusion (AFI) Report. 2015. Maya declaration report: Commitments into action.

Arun, T., Kamath, R., (2015). Financial inclusion: policies and practices. IIMB Manag. Rev. 27 (4), 267-287.

Babajide, A.A., Adegboye, F.B., Omankhanlen, A.E., (2015). Financial inclusion and economic growth in Nigeria. Int. J. Econ. Financ, 5 (3), 629-637.

Beck, T. (2016). Financial Inclusion-measuring progress and progress in measuring. Paper presented at the Fourth IMF Statistical Forum, "Lifting the Small Boats: Statistics for Inclusion Growth," Washington, D.C.

Boukhatem, J., (2016). Assessing the direct effect of financial development on poverty reduction in a panel of low-and middle-income countries. Res. Int. Bus. Finance 37, 214-230.

Collard S. (2010). Toward financial inclusion in the UK: progress and challenges. Public Money \& Management 27(1), 13-20.

Demirguc-Kunt, A. and Klapper, L. (2012), "Measuring financial inclusion: the Global Findex Database", Policy Research Working Paper No. 6025, World Bank.

Demirguc-Kunt, Klapper, and Singer (2012), by promoting financial inclusion, we help address and reduce inequalities, thereby reducing poverty and improving economic development.

Hanson, S. E. and J. C. Stein (2015), "Monetary policy and long-term real rates", Journal of Financial Economics, 115(3), 429-448.

Kim, D.W., Yu, J.S., Hassan, M.K., (2018). Financial inclusion and economic growth in OIC countries. Res. Int. Bus. Finance 43, 1-14.

Laeven, L., Levine, R. \& Michalopoulos, S. (2015). Financial innovation and endogenous growth. Journal of Financial Intermediation, 24, 1-24. 
Laeven, L., Levine, R., \& Michalopoulos, S. (2015). Financial innovation and endogenous growth. Journal of Financial Intermediation, 24(1), 1-24. https://doi.org/10.1016/j.jfi.2014.04.001.

Lee C.-C., Wang C.-W. \& Ho S.-J., Financial inclusion, financial innovation, and firms' sales growth, International Review of Economics and Finance (2019), doi: https:// doi.org/10.1016/j.iref.2019.11.021.

Leyshon A., Thrift N. (1993). The restructuring of the U.K. financial services industry in the 1990s: a reversal of fortune? Journal of Rural Studies 9(3), 223-241.

Leyshon A., Thrift N. (1994). Access to financial services and financial infrastructure withdrawal: problems and policies. Area 26, 268-275.

Leyshon A., Thrift N. (1995). Geographies of financial exclusion: financial abandonment in Britain and the United States. Transactions of the Institute of British Geographers 20(3), 312-341.

Liu, J., Li, X., Wang, S., (2020). What have we learnt from 10 years of fintech research? a scientometric analysis. Technol. Forecast. Soc. Change 155, 120022. https://doi.org/ 10.1016/j.techfore.2020.120022.

Loh, X.M., Lee, V.H., Tan, G.W.H., Hew, J.J., Ooi, K.B., (2019). Towards a cashless society: the imminent role of wearable technology. J. Comput. Inform. Syst. 1-11. https:// doi.org/10.1080/08874417.2019.1688733.

Merton, R. C. (1995). Financial innovation and the management and regulation of financial institutions. Journal of Banking \& Finance, 19, 461-481.

Miller, M. H. (1986). Financial innovation: The last twenty years and the next. Journal of Financial and Quantitative Analysis, 21, 459-471.

Mlambo, K., Ncube, M., (2011). Competition and efficiency in the banking sector in South Africa. Afr. Dev. Rev. 23 (1), 4-15.

Nakamura, E. and Steinsson, J. (2018), "High Frequency Identification of Monetary Non Neutrality: The Information Effect," Quarterly Journal of Economics, 133 (3), 12821330.

Pradhan, R.P., Arvin, B.M., Norman, N.R., Nair, M., dan Hall, J.H., (2016). Insurance penetration and economic growth nexus: cross-country evidence from ASEAN. Res. Int. Bus. Finance 36, 447-458.

Qamruzzaman, M. \& Jianguo, W. (2018). Investigation of the asymmetric relationship between financial innovation, banking sector development, and economic growth. Quantitative finance and economics, 2(4), 952-980.

Sahay, R., Cihak, M., N'Diaye, P., Barajas, A., Mitra, S., Kyobe, A., et al. (2015). Financial inclusion: Can it meet multiple macroeconomic Goals? IMF Staff Discussion Note 15/17, September.

Semerikova, E., (2019). Payment instruments choice of Russian consumers: reasons and pain points. J. Enterprising Communities 14 (1), 22-41. https://doi.org/10.1108/ JEC-09-20190089.

Silber, W. L. (1983). The process of financial innovation. The American Economic Review, 73, 89-95.

Tufano, P. (2003). Financial innovation. Handbook of the Economics of Finance, 1, 307- 335.

Wachtel, P. (2003). How much do we really know about growth and finance. Federal Res Bank Atlanta Econ Rev, 33-47. 